\title{
Kahramanmaraş'ta Bir Erken Cumhuriyet Dönemi Evi: Çiftarslan Evi
}

\author{
Aslı PAKÖZ ${ }^{1}$
}

\section{Öz}

$\mathrm{Bu}$ çalışmada, Kahramanmaraş şehir merkezinde bulunan ve sahip olduğu tarihi ve mimari özellikleri ile korunması gerekli bir yapı olan Çiftarslan Evi'nin incelenerek, evle ilgili bilgilerin belgelenmesi amaçlanmıştır. Bunun için çeşitli kaynaklara başvurulmuş ve yapı yerinde incelenmiştir. Yapılan literatür araştırmasında; Çiftarslan Evi ile ilgili bilimsel bir çalışmaya rastlanılmamıştır ancak Maraş Evleri'nin genel özellikleri ile ilgili yapılmış çalışmalar mevcuttur. Çiftarslan Evi ile ilgili tarihsel ve mimari bilgiler için; Kahramanmaraş Müze Müdürlüğü arşivinden yapının tescil fişine ve Çukurova Üniversitesi Mimarlık Bölümü öğrencileri tarafından hazırlanan eve ait rölöve çizimlerine ulaşılmıştır. Ayrıca yerinde incelenen Çiftarslan Evi'nin iç mekânları gezilerek güncel fotoğrafları çekilmiş ve ev sahibi ile görüşülerek evle ilgili bazı tarihsel bilgiler edinilmiştir. Bu bilgiler sonucunda Çiftarslan Evi'nin sahip olduğu özgün mimari özellikler yanında, son yüzyıl içinde değişen toplumsal yaşamdan izler barındırması ve Erken Cumhuriyet dönemi geleneksel konut mimarisi ile ilgili fikir vermesi bakımından önemli bir yapı olduğu görülmüştür.

Anahtar Kelimeler: Kahramanmaraş, Erken Cumhuriyet dönemi, Geleneksel ev, Çiftarslan Evi.

\section{A House From The Early Republican Period In Kahramanmaraş: Çiftarslan House}

\begin{abstract}
This study documents comprehensive information about the Çiftarslan House, which is located in Kahramanmaraş and must be preserved for its historical and architectural properties. To this end, the structure was examined on site in relation to various sources. An extensive literature analysis showed that, although several research studied the general characteristics of Maraş houses, no scientific research has focused on the Çiftarslan House. The main data source for the historical and architectural background of the house was the registration slips of the building obtained from the Kahramanmaraş Directorate of Museum Archive and survey drawings of the house prepared by the students of Çukurova University Department of Architecture. In addition, interior photos of the Çiftarslan House were taken, and the homeowner was interviewed to gather historical information about the house. It was concluded that Çiftaslan House is a prominent structureas it has unique architectural features, encompasses traces from the changing social life of the last century, and sheds light onto the vernacular architecture in the Early Republican Period
\end{abstract}

Keywords: Kahramanmaraş, The Early Republican Period, Traditional house, Çiftarslan House.

\footnotetext{
${ }^{1}$ İstanbul Şehir Üniversitesi, Mimarlık ve Tasarım Fakültesi, İstanbul / Türkiye,

* İlgili yazar/Corresponding author: aslihanpakoz@gmail.com

Gönderim Tarihi / Received Date: 22.11.2019

Kabul Tarihi / Accepted Date: 08.06.2020
} 


\section{GíRiş}

Kahramanmaraş'ta bulunan Çiftarslan Evi'nin günümüzdeki durumunu belgelemeyi ve böylece korunmasına katkı sağlamayı amaçlayan bu çalışmada, öncelikle evin bulunduğu yerden ve evin yapıldığı dönemden söz edilecek, daha sonra araştırılan kaynaklardan evin tarihi ve mimari özellikleri ile ilgili ulaşılan bilgiler aktarılmaya çalışılacaktır².

Kahramanmaraş kale ve çevresinde gelişmiş bir şehirdir. Kale merkezli gelişmeye başlaması Dulkadiroğullları döneminde gerçekleşmiştir. Dulkadiroğlu tarafından vaktiyle ormanlık olan tepeler üzerindeki kale çevresinin merkez olarak seçilmesinin sebebi şehri hücumlardan daha iyi korumak içindir (Atalay, 1973, s.169). Günümüzde geleneksel şehir merkezini tanımlayan kalenin hemen eteğinde ulu cami, çarşı, medrese, hamam yapıları bulunmaktadır. Kalenin yakın çevresi de kale gibi yüksek tepelerle çevrilidir ve geleneksel konut yapıları bu tepelerdeki mahallelerde yer almaktadır. Bu mahalleler Kanlıdere, Uzunoluk deresi ve Şekerdere'nin derin vadilerle böldüğü; Kümbet, İt Tepesi ${ }^{3}$, Kale, Aladan ve Tekke tepelerinin yamaçlarında bulunmaktadır (Kanadıkırık, 1972, s. 254).

Çiftarslan Evi, Kahramanmaraş ili Merkez ilçesi Dulkadiroğlu'nda, Kayabaşı Mahallesi'nde ${ }^{4}$ ve geleneksel şehir merkezinin önemli bir ana ulaşım hattı olan Çukuroba Caddesi'nde bulunmaktadır (Şekil 1, 2) (Fot. 1). Evin üst parselinde 17. yüzyıl Osmanlı yapısı Çukuroba Cami ve yakın çevresinde 20. yüzyıl başından itibaren inşa edildiği tahmin edilen konut yapıları bulunmaktadır (Fot. 2-8).

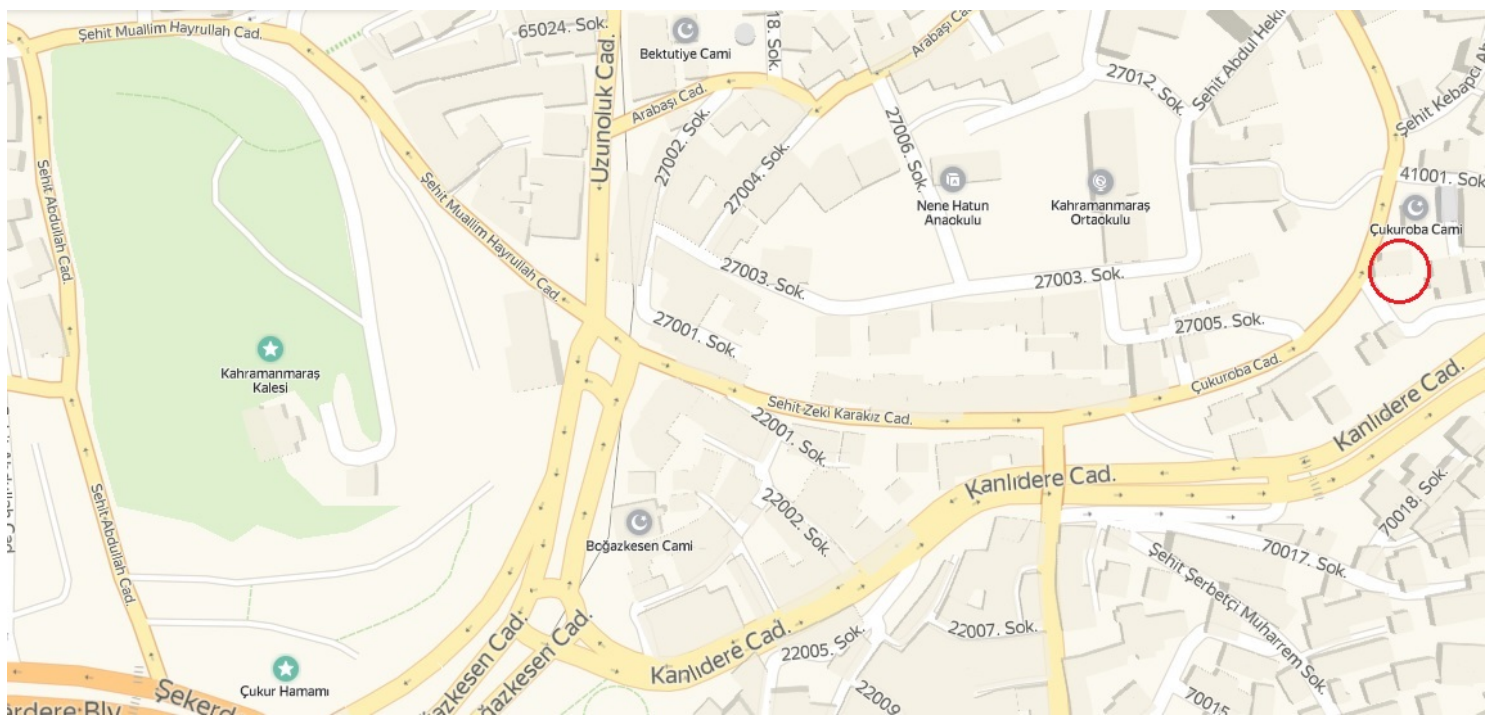

Şekil 1: Çiftarslan Evi ve yakın çevresi haritası (Yandex, 2019)

\footnotetext{
${ }^{2}$ Yapılan araştırmada Çiftarslan Evi ile ilgili bilimsel bir çalışmaya rastlanılmamıştır ancak Maraş Evleri'nin genel özellikleri ile ilgili yapılmış çalışmalar mevcuttur. Yazarın yüksek lisans tez çalışması da bu konudadır: Paköz, Aslıhan Ece, "Maraş Sivil Mimari Yapılarının Incelenmesi ve Gözlüklü Ali Evi Restorasyon Önerisi", YTÜ, Fen Bilimleri Enstitüsü, İstanbul 2013.

${ }^{3}$ Halk arasında İt Tepesi olarak bilinen yerin diğer adı Abarabaşı'dır.

${ }^{4}$ Kayabaşı Mahallesi'nin daha önceki isimleri; Eski Vakıf Tarla, Seksenler ve Çukuroba'dır. Kahramanmaraş'ın yakın tarihinde önemli olayların geçtiği yerlerden biri olan Kayabaşı Mahallesi, Maraş Milli Mücadelesi'nin ilk teşkilatlanan mahallelerindendir. Fransız Manastırı (halk arasında Abarabaşı Kilisesi ya da Belikendirliler Kilisesi olarak bilinen kilise) bu mahallede bulunmaktaydı. Cumhuriyet kurulduktan sonra faaliyete başlayan Türk Ocakları'nın Kahramanmaraş şubesi de bu mahalledeydi (Koç, 2010, s. 153).
} 


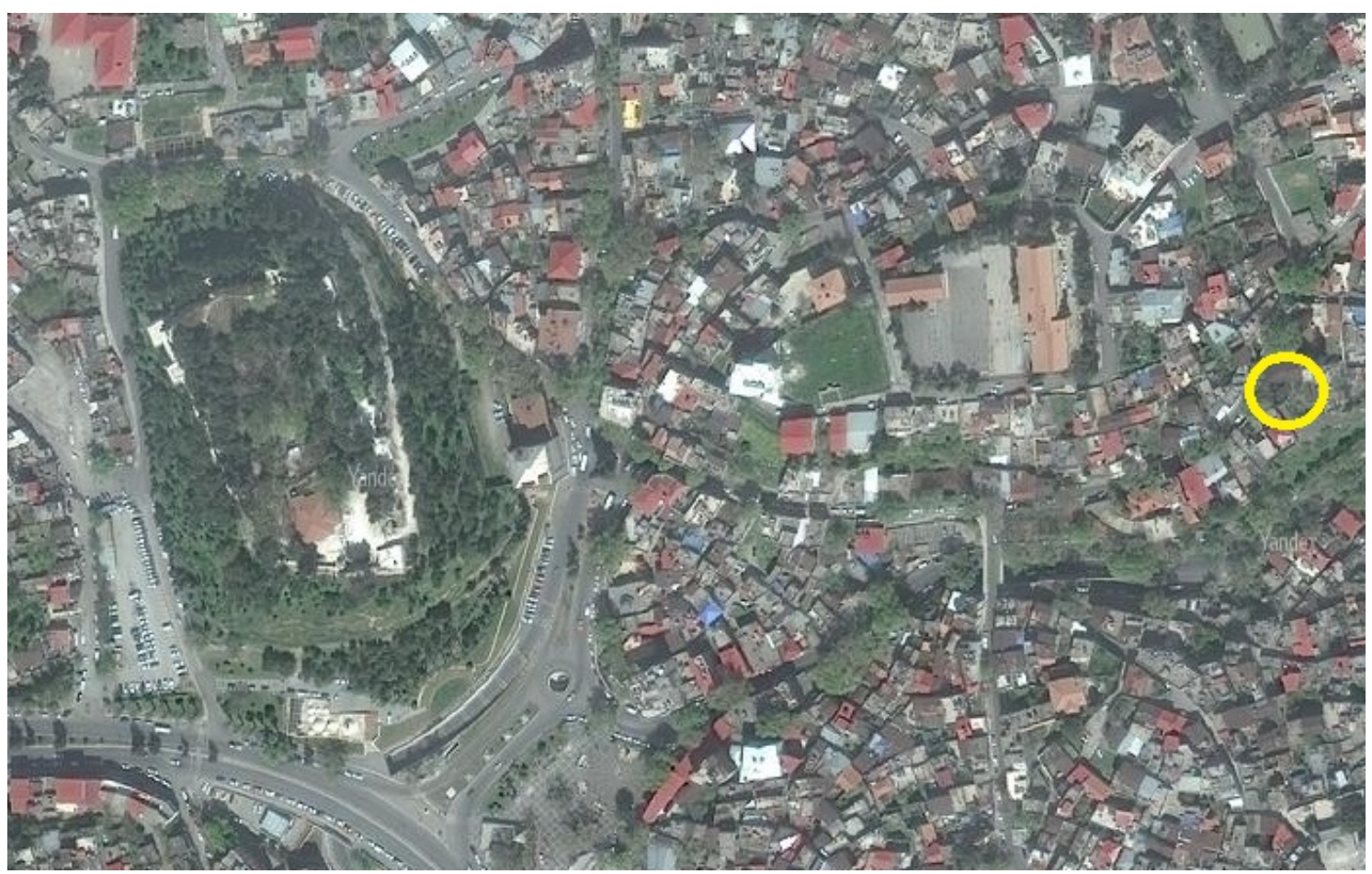

Şekil 2: Çiftarslan Evi ve yakın çevresi uydu görüntüsü (Yandex, 2019)

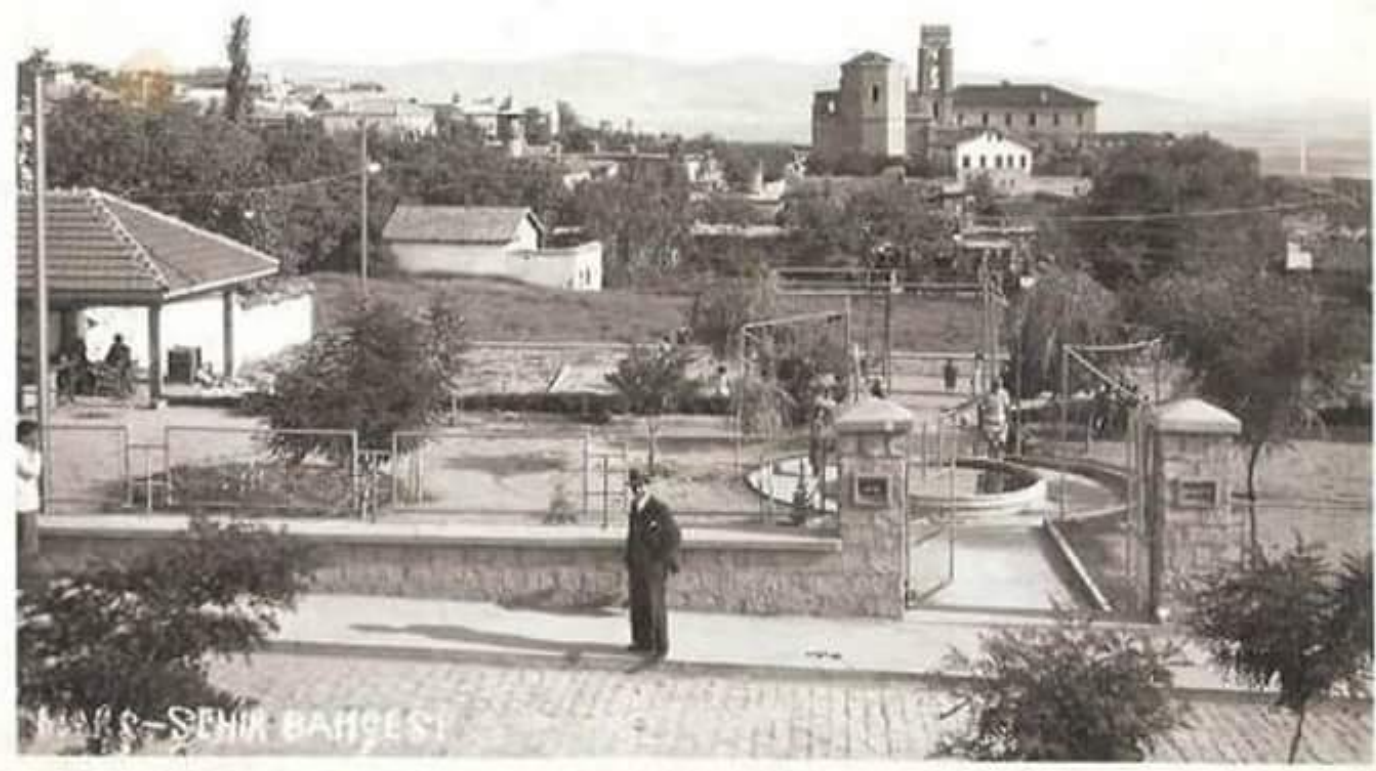

Fot. 1: Çocuk Bahçesi Parkı'ndan Kayabaşı Mahallesi'ne doğru bakış, Erken Cumhuriyet dönemi.

Geri planda görülen büyük yapı 1934-37 yılları arasında yıkılan Abarabaşı Kilisesi'dir (Anonim, 2012, s. 47). 


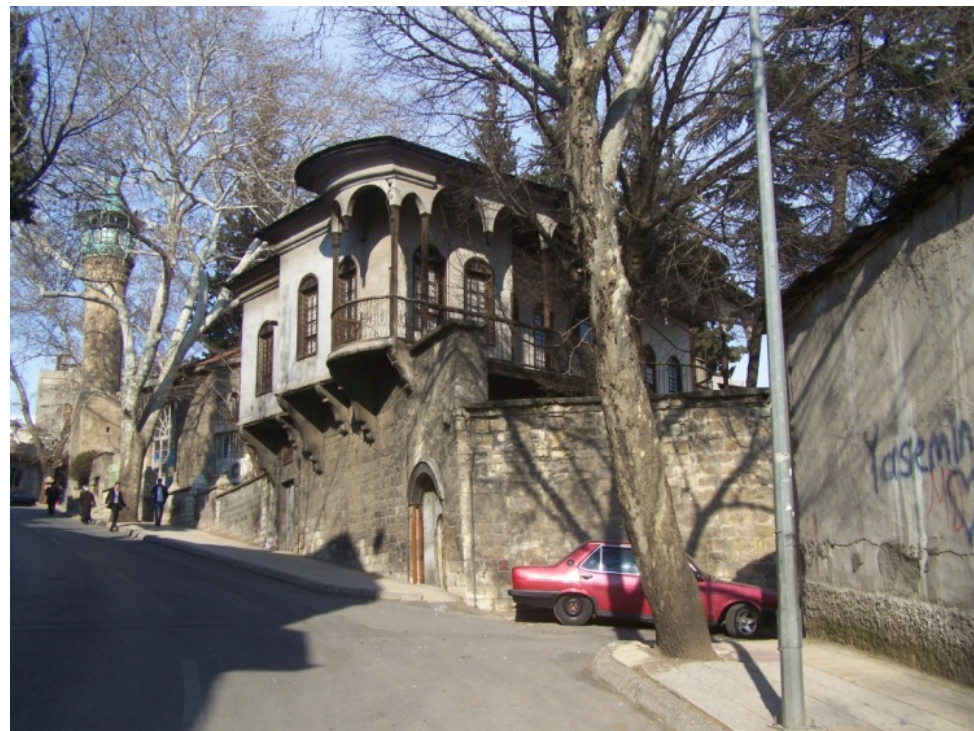

Fot. 2: Çiftarslan Evi ve üst parselindeki Çukuroba Cami (Aslı Paköz, 2019)

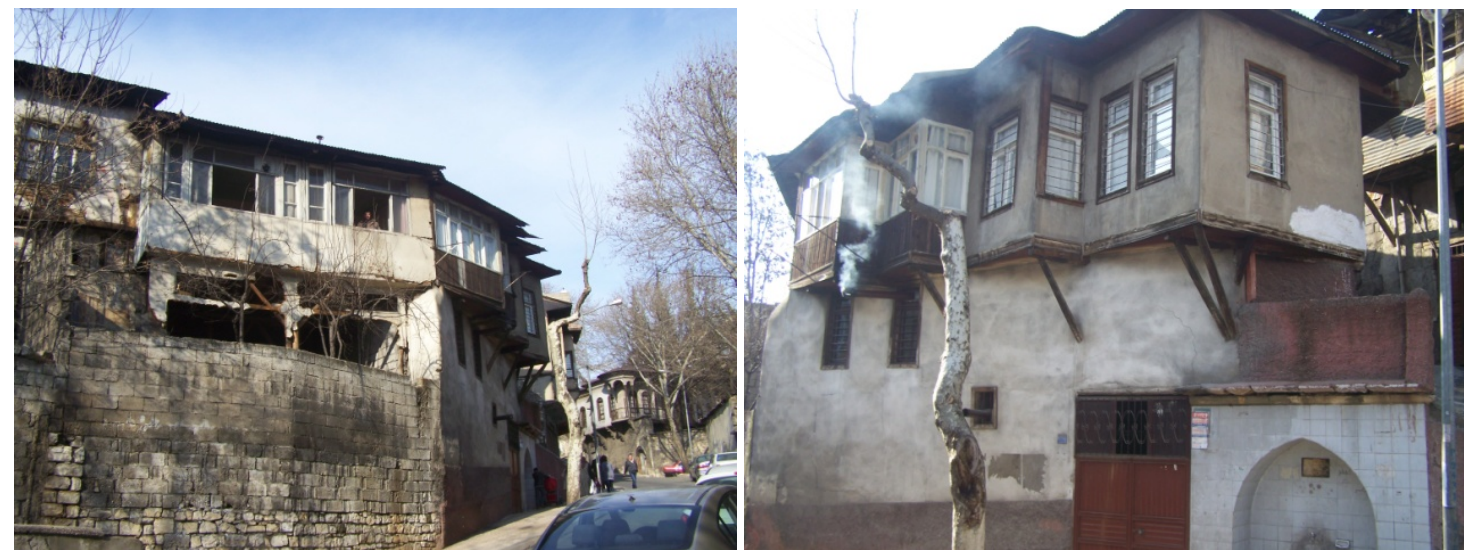

Fot. 3-4: Çiftarslan Evi'nin yakın çevresinde bulunan yapılar (Aslı Paköz, 2019)

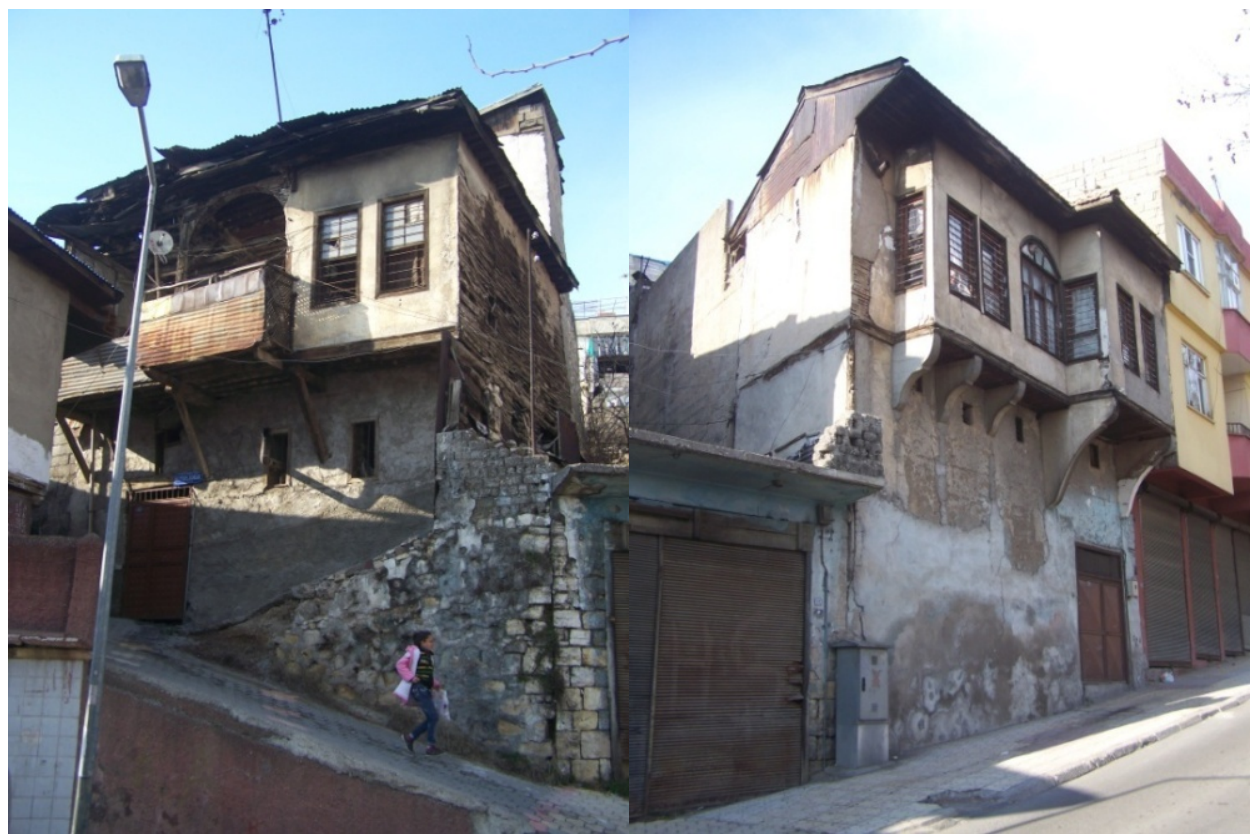

Fot. 5-6: Çiftarslan Evi'nin yakın çevresinde bulunan yapılar (Aslı Paköz, 2019) 


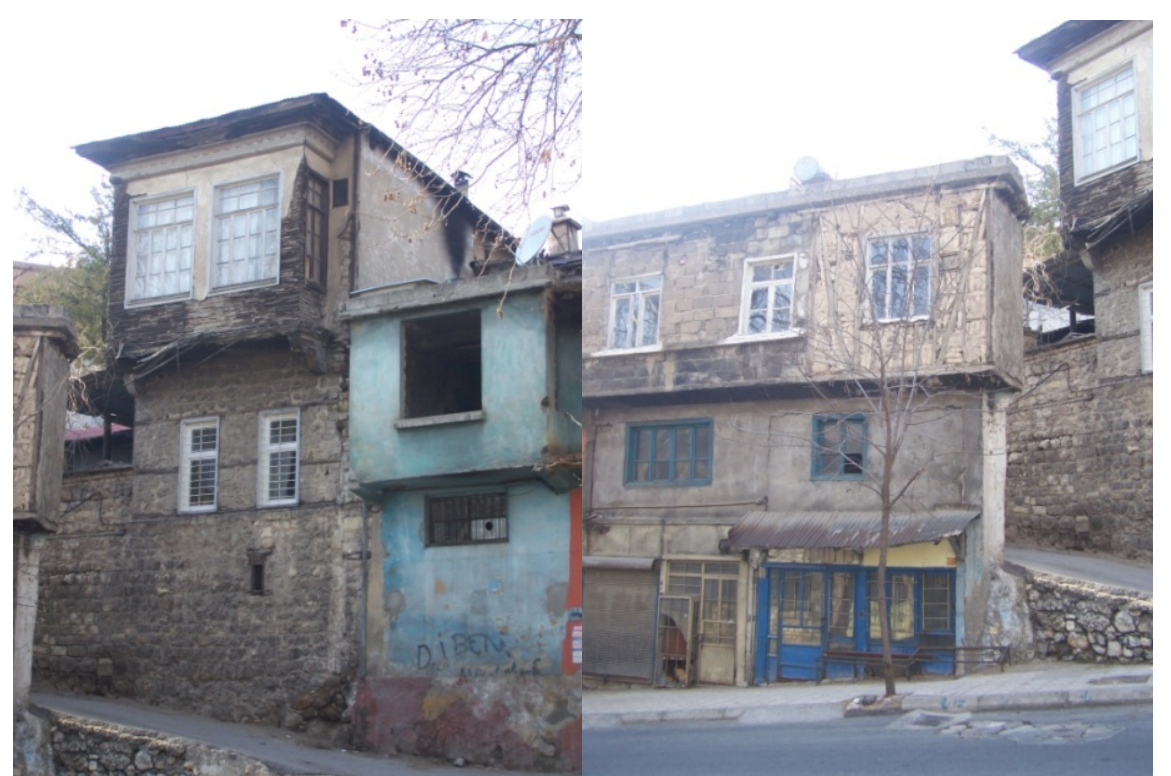

Fot. 7-8: Çiftarslan Evi'nin yakın çevresinde bulunan yapılar (Aslı Paköz, 2019)

Araştırılan kaynaklardan Maraş'ta günümüze ulaşan ve şehrin geleneksel sivil mimarisini oluşturan yarı kâgir yarı ahşap (alt katı taş, üst katı ahşap) evlerin 19. yüzyılın ikinci yarısından itibaren yapılmaya başlandığı anlaşılmaktadır. Bu dönemden önce şehirde düz toprak damlı kerpiç evler inşa edilmiştir. Bu konuda Besim Atalay 1900'lü yılların başında; "Maraş'ta çoğunlukla evler kerpiçtendir ve üzeri topraktır. Kiremit kullanılan yapıların çoğu Hristiyanlara mahsustur" diye belirtmektedir (Atalay, 1973, s.169). Bu konuda Ali Cevad'ın 19. yüzyıl sonlarında yayımlanan Memalik-i Osmaniye'nin Tarih ve Coğrafya Lügati adlı eserinde ise: "Bugünlerde İstanbulkari yarım kağirhane ve güzel güzel binalar dahi olunarak şehre hoş bir manzara verilmektedir" şeklinde bilgi verilmektedir (Köker, 2010, s. 279). Aynı şekilde 1871 yılı Maraş Sancağı Salname kayıtlarında, şehirdeki evlerin ve binaların büyük kısmının kerpiçten inşa edildiği ancak İstanbul'dakilere benzer yarı kâgir, üzeri kiremitlerle örtülü konak tipi meskenlerin inşa edilmeye başlandığı kaydedilmiştir (Toroğlu 2008, s. 212). $\mathrm{Bu}$ bilgilere göre, Kahramanmaraş'ta günümüze ulaşan geleneksel konutların, 19. yüzyılın sonu ve daha sonrasında inşa edilmiş Geç Osmanlı ve Erken Cumhuriyet dönemi yapıları olduğu söylenebilir. Şehrin yavaş da olsa gelişmeye başladığı bu yıllarda şehirde kâgir evler çoğalmaya ve yapıların mimari özellikleri çeşitlilik göstermeye başlamıştır. Böyle bir dönemde inşa edilen Çiftarslan Evi de kendine özgü mimarisi ile bu çeşitliliğin görüldüğü örneklerden biridir.

Erken Cumhuriyet döneminde yaşanan toplumsal değişimlerle birlikte Kahramanmaraş'ta evler birbirinden farklılaşmaya başlasa da evlerin geniş ailelerce bir arada kullanımı bir süre daha devam etmiştir. Yakın bir döneme kadar uzanımları görülen bu uygulamada geniş ailelerin, aynı evde ve az sayıda oda içerisinde birlikte yaşamasının orta ve üst gelir grubu aileler için de geçerli olduğu Çiftarslan Evi örneğinde görülmektedir. Çiftarslan Evi'nin sahibi Alaiddin Çiftarslan ${ }^{5}$ ile yapılan görüşmede edinilen bilgiye göre, kendisinin çocukluğunda ve gençliğinde, evin alt katında; halasının, amcasının ve kendisinin ailesi birlikte yaşamışlardır (Fot. 9).

\footnotetext{
${ }^{5}$ Çiftarslan Evi'nin yerinde incelenmesi ve evle ilgili bilgiler almak için Alaiddin Çiftarslan ile 01.01.2019 tarihinde görüşülmüştür. Bu makalenin yayına hazırlandığı günlerde (Mayıs 2020) vefat eden Alaiddin Çiftarslan'ı saygıyla anıyorum.
} 


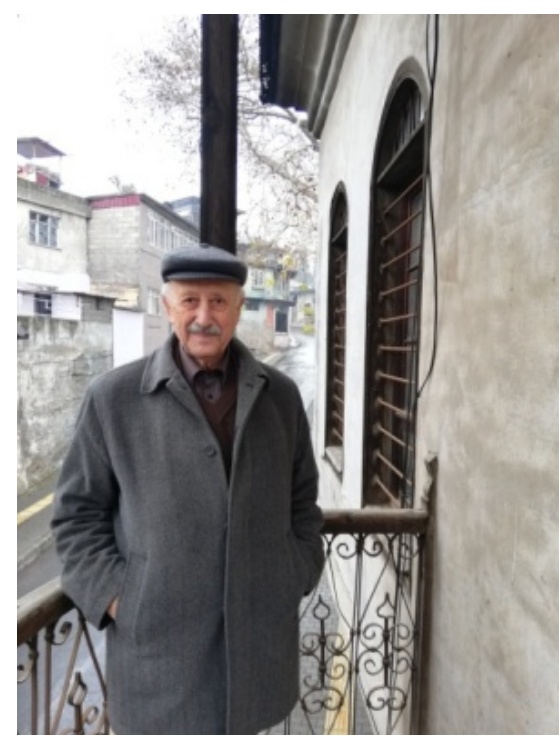

Fot. 9: Alaiddin Çiftarslan (Aslı Paköz, 2019)

\section{MIMARİ ÖZELLİKLERİ}

Çiftarslan Evi, "Haşir Mehmet" olarak bilinen Mehmet Çiftarslan tarafından 1928 yılında yaptırılmıştır. Manifaturacılık işiyle uğraşan Mehmet Çiftarslan, evi Nacar (Marangoz) Mehmet Usta'ya yaptırmıştır. Bu çalışmada evle ilgili tarihsel bilgilerin alındığı Alaiddin Çiftarslan, Mehmet Çiftaraslan'ın torunudur. Alaiddin Çiftarslan'ın verdiği bilgiye göre Çiftarslan Evi'ni yapan usta, bugün Maraş Kültür Evi olarak kullanılan, Kocabaş Konağı olarak bilinen yapıyı da aynı tarihte inşa etmiştir ${ }^{6}$ (Fot. 10).

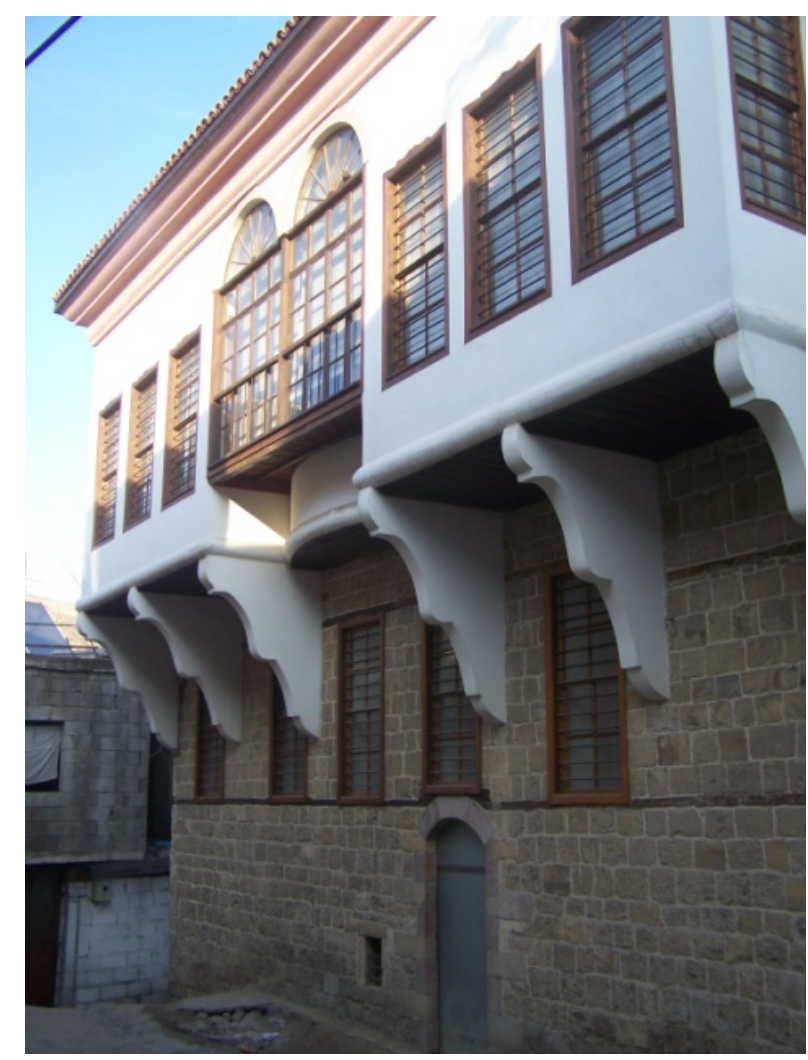

Fot. 10: Kocabaş Evi (Aslı Paköz, 2013)

\footnotetext{
${ }^{6}$ Bugün "Kocabaş Konağı" olarak bilinen evi yaptıran kişi Alaiddin Çiftarslan'ın dedesidir (annesinin babası).
} 
Evin alt kat çevre duvarları kaba yonu taş malzemeyle ve yöresel olarak 'sıra duvar' olarak isimlendirilen yöntemle yapılmıştır. Pencere ve kapı kenarları ise ince yonu taşla çevrilidir. Alt kat ara duvarları ahşap taşıyıcı arası kerpiç dolgu sistemle; üst kat ise ahşap taşıyıcı üzeri bağdadi çıta çakılarak yapılmıştır. Balkonu ve çatı saçağını ahşap direkler taşımaktadır. Balkonu taşıyan ahşap direkler taş kaideye oturur. Evin çatısı sac kaplamadır ve günümüze kadar böyle gelmiştir.

İki kattan oluşan Çiftarslan Evi'nin zemin katında dört oda, sofa, depo ve mutfak; birinci katında ise üç oda, sofa, mutfak, banyo, tuvalet ve balkon bulunmaktadır ${ }^{7}$ (Şekil 3,4). Zemin kata bir oda ile üst kattaki ıslak hacimler yapıya sonradan eklenmiştir. Çiftarslan, evin tuvalet mekânının önceden evin dışında, bahçede bulunduğunu söylemiştir.

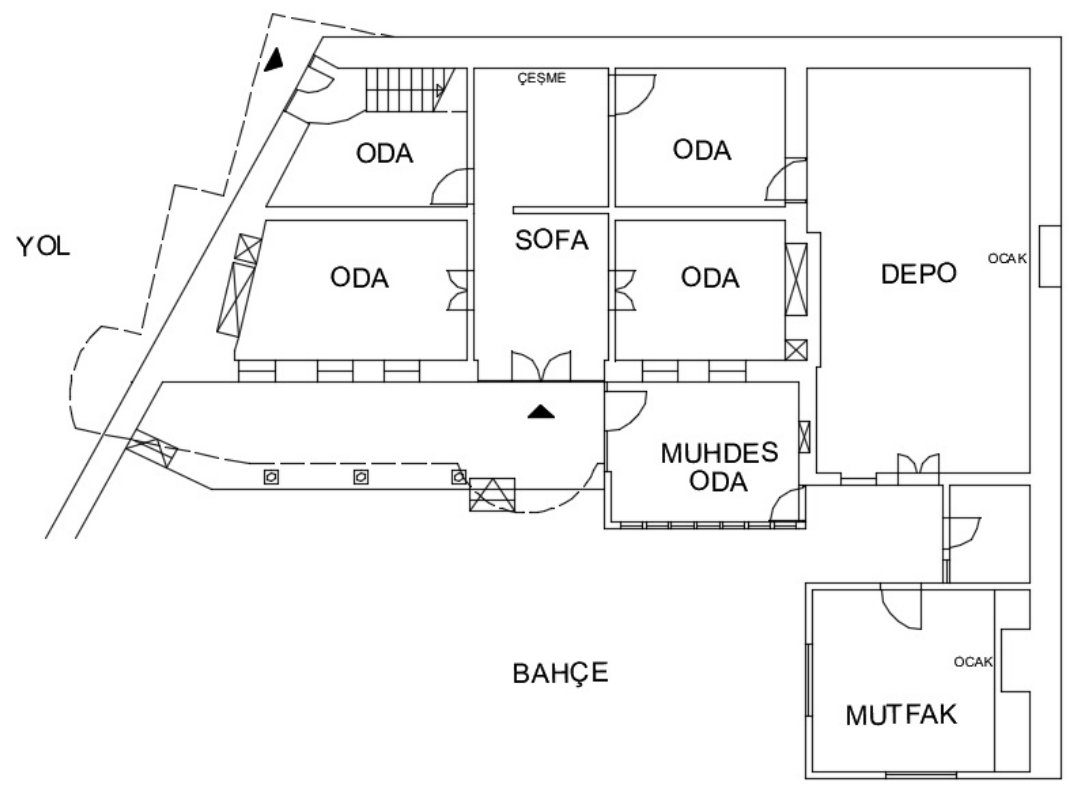

Şekil 3: Çiftarslan Evi zemin kat planı (Anonim, 1998, s. 18) ${ }^{8}$

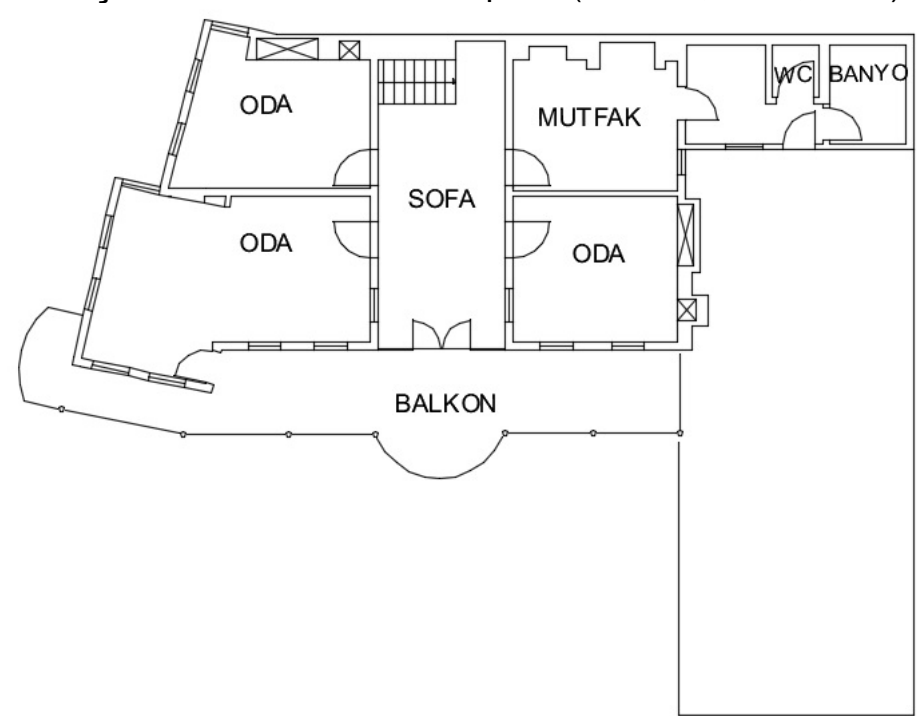

Şekil 4: Çiftarslan Evi birinci kat planı (Anonim, 1998, s. 19)

\footnotetext{
${ }^{7}$ Burada verilen bilgilerin bir kısmı daha önce; yazarın Alkış Dergisi'nde yayınlanan yazısında yer almıştır (Paköz, Aslı, "Geleneksel Maraş Evlerinin Sembolü: Çiftarslan Evi", Alkış Dergisi, S.105, Kahramanmaraş 2019, ss.16-17).

${ }^{8}$ Makalede kullanılan, Çiftarslan Evi'ne ait krokiler; Çukurova Üniversitesi, Mimarlık Bölümü, Tarihi Yapıları Koruma Yaz Okulu'nda yapılan çalışmaların yayınlandığı çalışma kitapçığındaki rölöve çiziminin yazar tarafından sadeleştirilmesiyle oluşturulmuştur.
} 
Zemin kattaki sofada, girişin tam karşısındaki taş duvarda bir çeşme bulunmaktadır (Fot. 11). Çiftarslan, çocukluğunda bu çeşmeden sürekli su aktığını söylemiştir. Ayrıca, o günlerde her mahallede, üstü kapalı, taştan yapılma bir taksim havuzu bulunduğunu ve bu taş havuzun kenarından, kaneden ${ }^{9}$ yapılma yollarla evlere dağıtılan suyun, evlerdeki çeşmelere bağlandığı bilgisini aktarmıştır.

Çiftarslan'dan alınan bilgiye göre, günümüzde evin katları arasında bağlantıyı sağlayan ahşap merdiven ve merdivenle bağlantılı olarak yapılan ara kattaki depo muhdestir ${ }^{10}$ (Fot. 12). Özgün merdivenin kaldırılıp yerine yeni bir merdiven yapılması, evin üst katının 1942 yılında kiraya verilmesi sırasında gerçekleşmiştir. Bu dönemde, özgün merdiven kaldırılmış, dışarıdan eve yeni bir giriş açılarak, buraya bir kapı ve merdiven eklenmiştir. Yapılan çalışmalarda evin özgün merdiveni ile ilgili bir belgeye ya da fotoğrafa ulaşılamamıştır. Ancak, evin planı iç sofalı geleneksel Maraş evlerinin planları ile birlikte değerlendirildiğinde ve Çiftarslan Evi'ni yapan ustanın aynı dönemde yaptığı Kocabaş Konağı'nın planı ile kıyaslandığında merdivenin olası yerinin sofada, evin ana girişinin karşı duvarında, Kocabaş Konağı'ndaki benzer bir formda olduğu tahmin edilmektedir (Şekil 5).

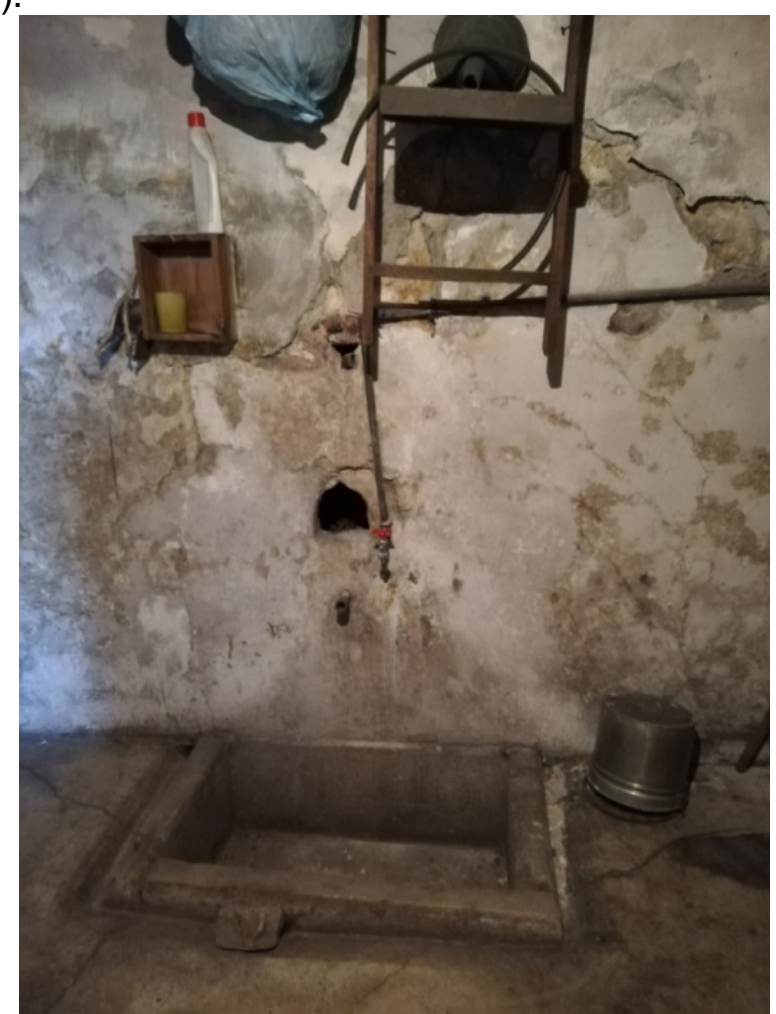

Fot. 11: Sofadaki çeşme (Aslı Paköz, 2019)

\footnotetext{
${ }^{9}$ Pişmiş toprak kiremit oluk.

${ }^{10}$ Muhdes: Korunması gerekli bir yapıya ilave edilmiş olan ve yapıyla bağdaşmayan ek (Hasol, 2014, s. 333).
} 


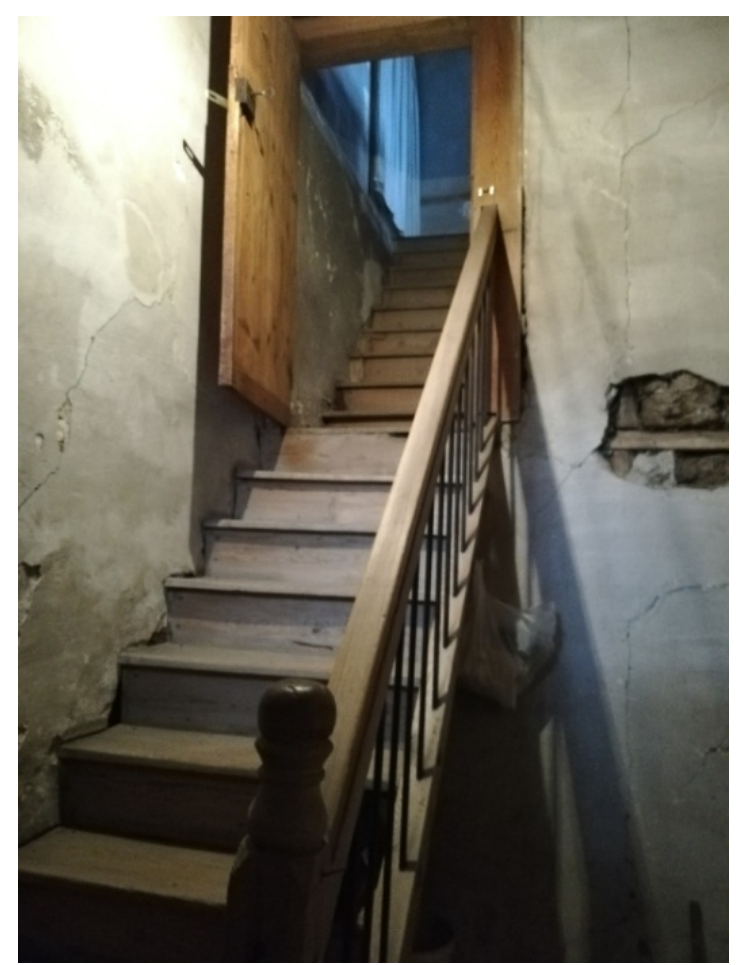

Fot. 12: Sofadaki muhdes merdiven (Aslı Paköz, 2019)

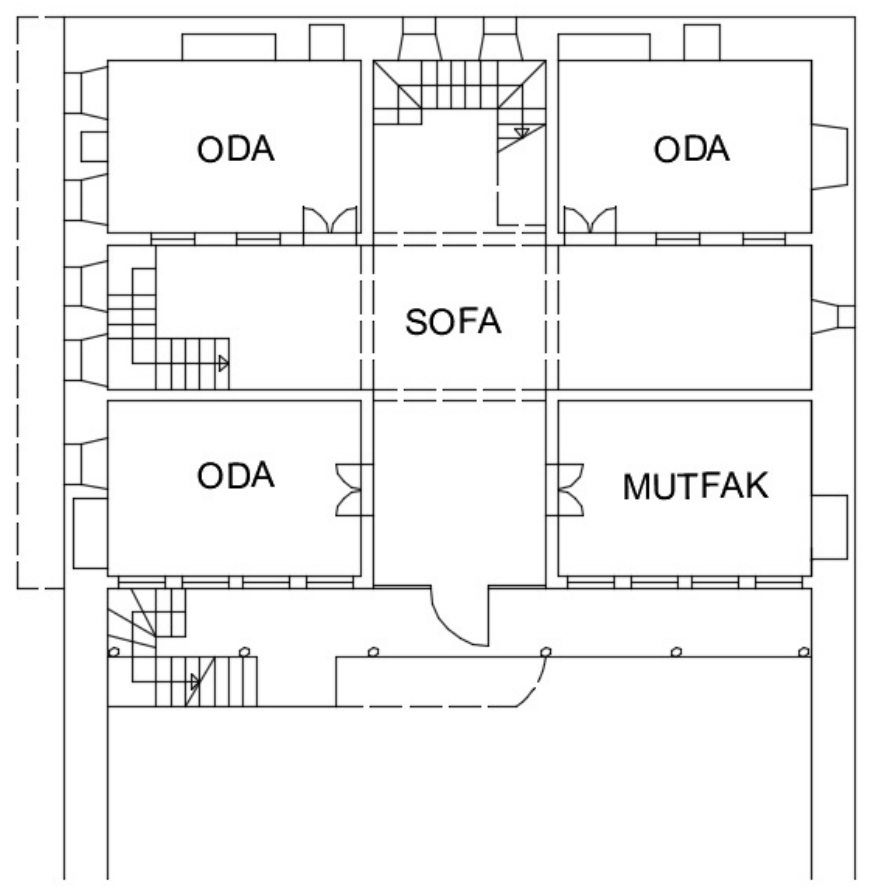

Şekil 5: Kocabaş Konağı birinci kat planı (Paköz, 2013, s. 77)

Çiftarslan, mutfağın üst örtüsünün özgün halinde toprak dam olduğunu, daha sonra betona çevrildiğini belirtmiştir. Toprak dam için geçmiş günlerde kullanılan "loğ taşı" halen evde durmaktadır. Hem mutfağın hem de deponun taş duvarında ocak bulunmaktadır; bugün kullanılmasa da ekmek yapılan günlerden kalma sac halen ambardaki ocaktadır. Mekânların özgün ahşap kapıları, pencereleri ve dolapları durmaktadır (Fot. 13,14). 


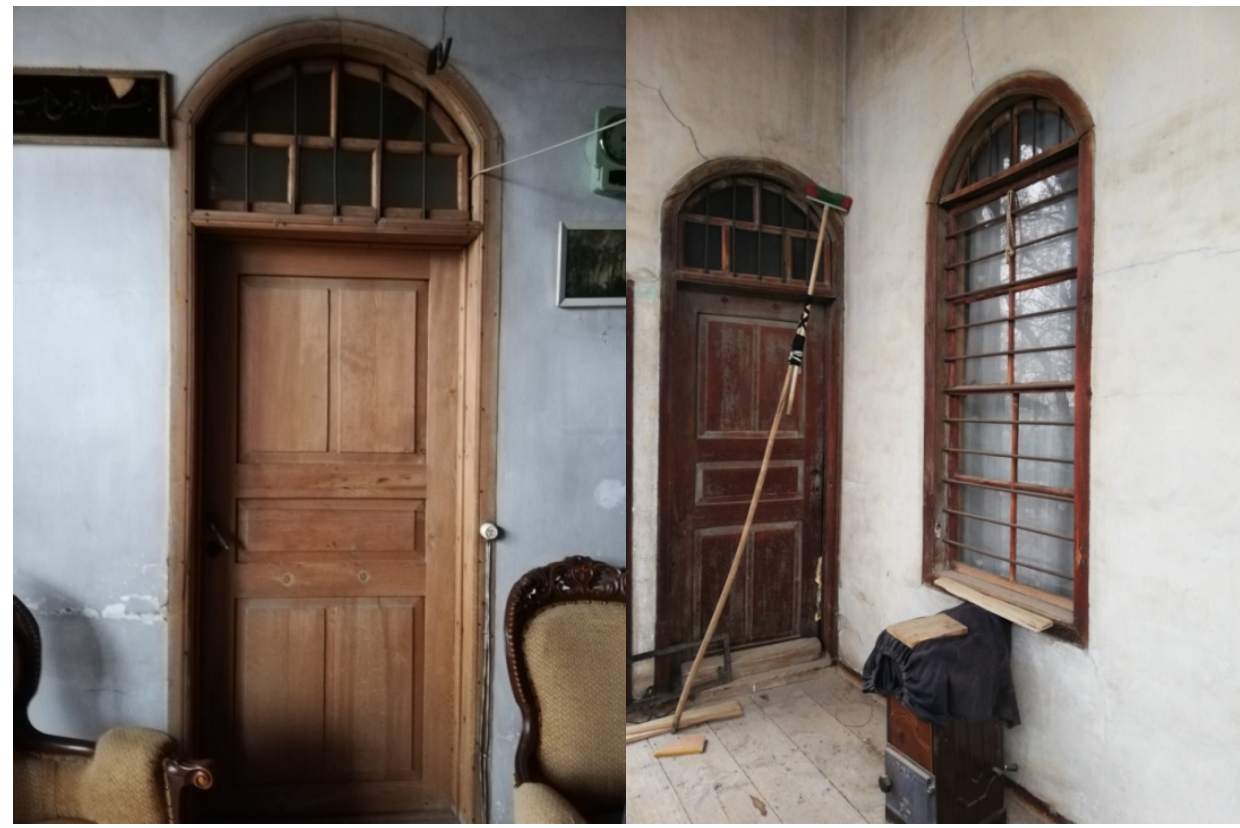

Fot. 13-14: Kapı ve pencerelerden örnekler (Aslı Paköz, 2019)

Çiftarslan Evi, Sedad Hakkı Eldem'in yaptığı sınıflandırmaya dahil edilmek istenirse, ilk bakışta iç sofalı ya da "karnıyarık" olarak isimlendirilen evler sınıfına dahil edilebilir (Eldem, 1968 ,s.16). Ancak belirli bir sınıf altında toplanan evlere yakından bakıldığında sınıflandırma tanımı ile çelişen evlerle karşılaşılmaktadır ${ }^{11}$. Çiftarslan Evi örneğinde, şematik plan üzerinden bakıldığında bile bu çelişki yaşanmaktadır. Sofanın iki yanına dizilen odalarla sofa içte kaldığından bu eve iç sofalı ev denilse de ev içe dönük bir yapıda değildir. Yapının güney cephesinde boydan boya uzanan dış sofa ya da ayazlık olarak nitelendirilebilecek açık mekânlar her iki katta da bulunmaktadır.

Yapıya ait tescil fişinde de sofalarla ilgili terminolojik bir karışıklık yaşandığı görülmektedir ${ }^{12}$. Odaların arasındaki mekân için bir yerde iç sofa denilmiş, başka bir yerde ise orta iç sofa diye bir tabir kullanıımıştır. Ayrıca alt kattaki dış mekân için

\footnotetext{
${ }^{11}$ Bu sorun sadece Eldem'in Türk Evi Tipolojisi için geçerli değildir. Bu konuda Eldem'in ardından başka araştırmacılar tarafından yapılan çalışmalarda da farkı isimlendirmelerle genelleştirmeler yapılmaya devam ettiği görülmektedir.

${ }_{12}$ Çiftarslan Evi'nin Kahramanmaraş Müze Müdürlüğü arşivindeki tescil fişinin bulunduğu dosyada evin adı Cemil Çiftarslan (Çiftarslanların Evi) olarak kayıtıdır. Dosyada evin yeri Kayabaşı Mahallesi 834 Ada, 4 Parsel olarak, tescil tarihi ise Taşınmaz Kültür ve Tabiat Varlıkları Yüksek Kurulu'nun 1985 tarih ve 1629 nolu kararı ile şeklinde belirtilmiştir. Tescil fişindeki "ayrıntılı tanım" bölümünde yazan bilgiler şunlardır:

"Bina arsanın kuzeyine güneye cepheli olarak yerleştirilmiştir. Avlu etrafı yüksek bahçe duvarı ile çevrelenmiştir. Batıda iki tane giriş kapısı vardır. Bir tanesi yuvarlak taş kemerli kavsara içinde enikli ahşap bahçe kapısı, diğeri dikdörtgen kavsara içinde ahşap ana binaya giriş kapısıdır.

Zemin kat: Avludan üç basamak merdivenle sahanlığa çıkılmaktadır. Ahşap sütunlu sahanlık ve avlu dikdörtgen taşlarla kaplanmıştır. Sofaya giriş sivri kemerli camla kapatılmış kapıdan olmaktadır. İç sofaya karşılıklı iki oda açılmaktadır. Sofanın kuzeyi sonradan kapatılmıştır. Bu kısımda dikdörtgen havuzlu bir akar çeşme bulunmaktadır. Buranın solunda üst katın merdiven boşluğu, sağında ise bir oda bulunmaktadır. Odanın yan tarafa çıkış kapısı vardır. Geç devirlerde bu kısmın alt katta güneyine mutfak, banyo ve tuvalet üst katta ise banyo tuvalet ve teras ilave edilerek yarı kapalı bir mekân oluşturulmuştur. Aslında burası ev seviyesinde doğusunda ocak bulunan zemini taş kaplı zahire yapmak için kullanılan bir mekânmış, pencereler yuvarlak kavsaralı uzun, tavan ahşapla kapatılmıştır.

Üst kat: Aynı plan üstte de uygulanmıştır. Batıda beş elibelinde şeklinde payanda ile üç kademeli olarak genişleme yapılmıştır. Orta iç sofaya merdivenle ulaşılmaktadır. Buraya dört kapı açılmaktadır. Bunlardan solda kuzeyde bir oda, güneyde ise birbirine açılan iki oda bulunmaktadır. Camlı kapı ile geçilen ikinci oda hem payanda ile sokağa hem de ön sofaya doğru çıkıntı yapmaktadır. Sağ tarafta öndeki mekân oda, arkadaki ise ocaklı bir mutfaktır. Mutfaktan sonradan ilave edilen banyo ve tuvalete geçilmektedir. Bu kısmın güneye doğru uzantısı teras görünümündedir. Ön sofada sekiz ahşap sütun bulunmaktadır. Bunlar yuvarlak kemerlerle birbirine bağlanmıştır. Kemer açıklıkları değişik ölçülerdedir. Süsleme amacıyla üç yerde sütunsuz kemer açıklığı oluşturulmuştur. İç sofanın çıkışının karşısına yarı dairevi bir çıkıntı yapılarak sofanın orta kısmı genişletilmiştir. Doğuda sofa sonradan ilave olan kısma birleştirilmiştir. Pencerelerin üst kısmı yuvarlak kavsaralı uzundur. Tavan düz ahşap kaplamadır.

Çatı eğik ve çinko ile kaplanmıştır. Pencereler ve sofa korkulukları demirlidir".
} 
sahanlık, üst kattaki dış mekân için ön sofa denilmiştir. Çiftarslan Evi'nde karşılaşılan bu durum, evlerin; sofasız ya da dış, iç, orta sofalı olarak çok genel bir üst başlıkta sınıflandırılması sonucu karşılaşılan zorluklara sadece bir örnek olmalıdır. Evler tek tek ve detayların görünebileceği bir ölçekte ele alındıklarında yapılan sınıflandırmaların yapıyı tarif etmek için yetersiz olduğu ortadadır.

Bahçe içinde konumlanan Çiftarslan Evi'nin, dışarıdan sadece Çukuroba Caddesi'ne bakan batı cephesi görülebilmektedir (Bkz. Fot. 2). Bu cephede zemin katta; bahçe taş duvarında bulunan ve evin bahçesine girişi sağlayan "enikli kapı"13 bulunmaktadır. İç içe geçmiş iki kapıdan oluştuğu için bu ismi alan ahşap kapılar Çiftarslan Evi'nde yuvarlak kemerli ve sac kaplamalıdır. Ayrıca batı cephesinde, evin üst katının ayrı olarak kullanıldığı dönemde yapıya eklenen muhdes bir kapı vardır. Aynı cephede üst katta; kademeli olarak yapılmış iki adet kapalı çıkma ve bir adet dairesel açık çıkma bulunmaktadır. Bu çıkmalı odalar, hem daha geniş bir alana hem de yönlendiği caddeyi farklı yönlerden gören çoklu bakışa sahiptir. Odaların pencereleri; dikdörtgen formda, yuvarlak kemerli ve demir ferforje parmaklıklıdır.

Cengiz Bektaş, Çiftarslan Evi'nin batı cephesinin bir fotoğrafına referans vererek "Maraş'ta Barok etkisi" ifadesini kullanmıştır (Bektaş, 2001, s. 77). Bektaş'ın bu yorumu özellikle batı cephesindeki dairesel çıkmayı işaret ederek yaptığı tahmin edilmektedir. Yapıdaki bu dairesel çıkma, sokağa, topografyaya uyumlu, yapıya karakteristik bir özellik katan özgün bir detaydır. Bu detay dışında yapının geri kalan bölümlerinde Barok etkisinin izlerini görmek pek mümkün değildir.

Evin güney cephesi bahçeye bakmaktadır (Fot. 15). Bu cephede iki katta da cephe boyunca uzanan açık mekânlar bulunmaktadır. Evin girişi de bu cepheden ve yapının orta aksındaki iç sofadan sağlanmaktadır. Giriş boşluğu, sivri kemerlidir ve burada sonradan camlı bir kapı eklenmiştir. Üst kattaki balkonun alt kattaki girişin üzerine gelen bölümü yuvarlak çıkmalıdır. Balkon ve üstündeki çatı saçağı, ahşap dikmelerle taşınmaktadır. Alt kattaki dikmeler, taş kaide üzerine oturmaktadır. Çatı saçağı altındaki dikmelerin arasında bağdadi çıtalarla yapılmış yuvarlak kemerler bulunmaktadır ${ }^{14}$ (Şekil 6).

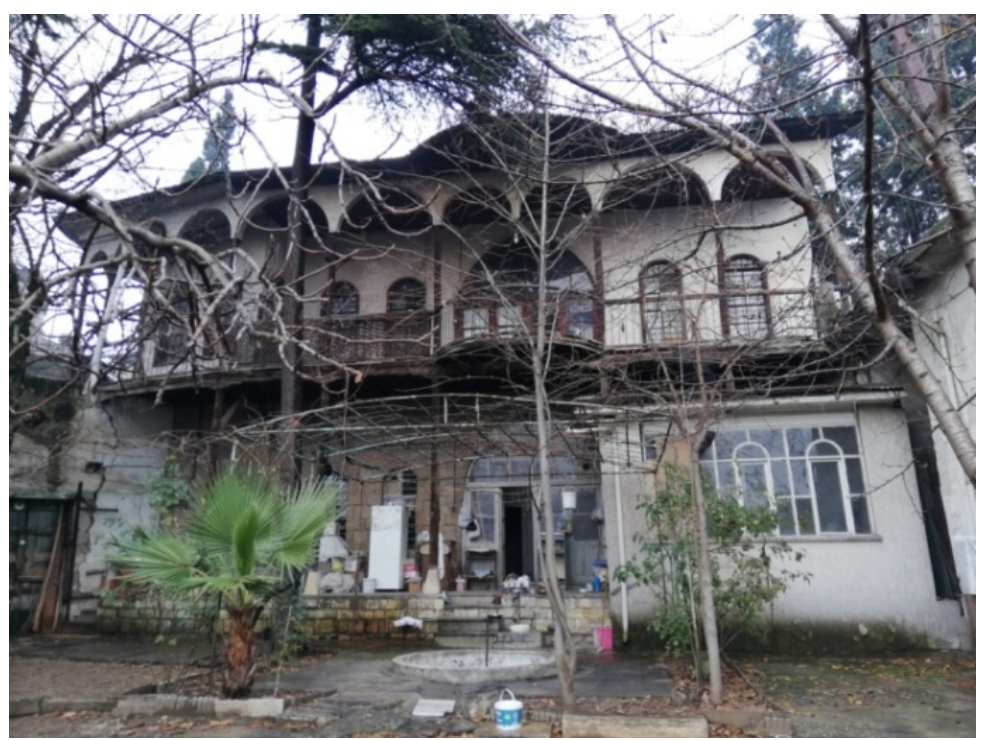

Fot. 15: Güney cephe (Aslı Paköz, 2019)

\footnotetext{
13 "Enikli kapı" ya da "kuzulu kapı" (Demir, 2010, s. 350).

${ }^{14}$ Alaiddin Çiftarslan'dan edinilen bilgiye göre; ev inşa edildiğinde, üst katın sıvası tamamlanmamış, bir süre sıvasız kalan üst katın sıvası daha sonra Alaiddin Bey'in babası tarafından yaptırılmış.
} 


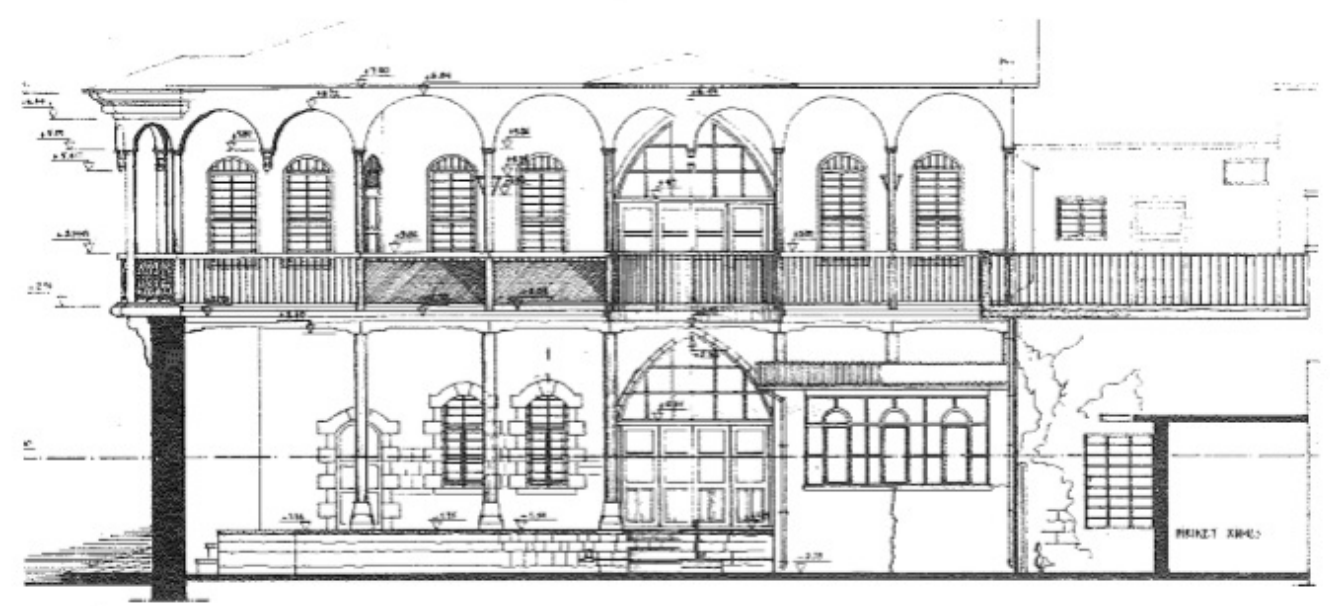

Şekil 6: Evin bahçeye bakan cephesinin rölövesi (Anonim, 1998, s. 15)

Çiftarslan Evi'nin önündeki geniş bahçenin içinde küçük bir havuz ile çeşitli ağaçlar ve güller bulunmaktadır (Fot. 17). Çiftarslan, evin ve bahçenin bulunduğu arsanın önceden incir bahçesi olduğunu ve dedesi Mehmet Çiftarslan'ın burayı Ermeni bir öğretmenden satın aldığında, bahçede küçük bir ev bulunduğu bilgisini aktarmıştır. Daha sonra arsa Mehmet Çiftarslan'a geçince, eski evin yerine bugünkü ev yaptırılmıştır. Arsanın eski sahibinin yetiştirdiği incir ağaçlarının çoğu yıllar önce bahçe duvarının göçmesi sonucu yerinden çıkmıştır ancak bir kaç tanesi halen durmaktadır. Bahçede incir ağacı dışında; dut ağacı, selvi ve büyük bir akçaağaç bulunmaktadır.

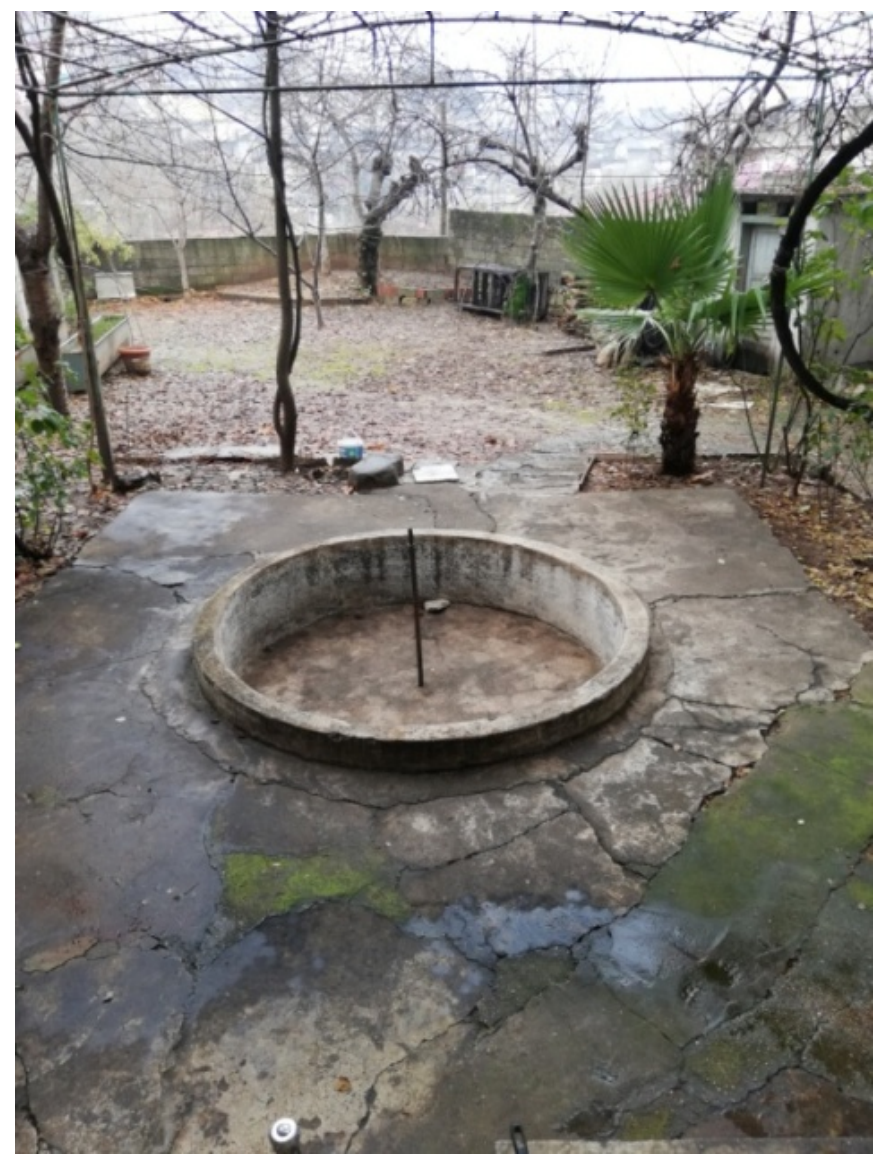

Fot. 17: Bahçedeki havuz (Aslı Paköz, 2019) 


\section{SONUÇ}

Çiftarslan Evi, Kahramanmaraş'ta günümüze ulaşan geleneksel konut yapıları arasında şehir halkının bildiği, değer verip sahip çıktığı bir ev olarak öne çıkmaktadır. Sahip olduğu özgün mimari özellikleriyle dikkat çeken bu evde yaşam, 1928'den 2017'ye, yani evin sahibi Alaiddin Çiftarslan'ın bu evde yaşayan annesi 94 yaşında vefat edinceye kadar, neredeyse bir asır devam etmiştir. Bir kaç yıldır ev kullanılmasa da çok kısa bir süre öncesine kadar evin sahibi tarafından evin ve bahçenin gerekli bakımının yapılmaya devam ettiği bilinmektedir. Çiftarslan Evi'nin inşa edildiği dönemdeki değişim ortamında, çeşitli özellikleriyle birbirinden farklılaşan evler üretildiği bilinse de bunların bir çoğu korunamamıştır. Bu yazının, günümüze kadar büyük ölçüde korunarak gelmiş olan Çiftarslan Evi'nin gelecek yıllarda da korunması için yapılacak çalışmalara katkı sağlaması umulmaktadır.

\section{KAYNAKLAR}

Acara, Meryem, "Bizans Dönemi'nde Maraş”, Dağların Gazeli Maraş, YKY, İstanbul 2010.

Anonim, Çukurova Üniversitesi, Mimarlık Bölümü, Tarihi Yapıları Koruma Yaz Okulu'nun çalışma kitapçığı, 1998.

Anonim, Maraş'ta Bir Devr-i Âlem, Kahramanmaraş Belediyesi Yayınları, 2012.

Atalay, Besim, Maraş Tarihi ve Coğrafyası, İstanbul 1973.

Bektaş, Cengiz, Halk Yapı Sanatı, Literatür Yayıncılık, İstanbul 2001.

Demir, Adnan, "Beşikten Mezara Maraş Folkloru", Dağların Gazeli Maraş, YKY, İstanbul 2010.

Eldem, Sedat Hakkı, Türk Evi Plan Tipleri, ITÜ Mimarlık Fakültesi Baskı Atölyesi, İstanbul 1968.

Hasol, Doğan, Ansiklopedik Mimarlık Sözlüğü, YEM Yayın, İstanbul 2014.

Kanadıkırık, Emrullah, "Maraş'ta Konut Tipleri", AÜDTCF Coğrafya Araştırmaları Dergisi, S.:5-6, Ankara 1972, ss. 253-281.

Koç, Kemalettin, Kahramanmaraş'ta Sosyal Hayatın Fiziki Yapıya Etkisi, Ukde Yayınları, Kahramanmaraş 2010.

Köker, Osman, "Osmanlı Dönemi'nden Maraş Sancağı Hakkında Bazı Veriler", Dağların Gazeli Maraş, YKY, İstanbul 2010.

Toroğlu, Emin, “Salnamelere Göre (1869-1908) Maraş Kazası'ında Nüfus, Yerleşme ve Ekonomik Faaliyetler", Maraş Tarihi ve Sanatı Üzerine, KSÜ Yayınları, Kahramanmaraş 2008.

Paköz, Aslıhan Ece, "Maraş Sivil Mimari Yapılarının Incelenmesi ve Gözlüklü Ali Evi Restorasyon Önerisi", YTÜ, Fen Bilimleri Enstitüsü, İstanbul 2013.

İnternet kaynakları:

Yandex, Son Erişim Tarihi: 15.05.2020:

https://yandex.com.tr/harita/103888/kahramanmaras/?l=sat\&\|l=36.932839\%2C37.5876 $\underline{13 \& z=17}$ 